\title{
Biochemical Diversity of Sweetpotato Genotypes
}

\author{
L.A. Ochieng ${ }^{1,2}$ \\ ${ }^{1}$ University of Kabianga, Department of Horticulture, P.O Box 2030-20200, Kericho, Kenya \\ 2Jomo Kenyatta University of Agriculture and Technology Department of Horticulture, P.O. Box \\ 62000-00100, Nairobi, Kenya \\ liloochieng@yahoo.com
}

Keywords: Ipomoea batatas, Kenya, nutrient composition

\begin{abstract}
A comprehensive analysis of the variation in sweetpotato [Ipomoea batatas (L.) Lam.] is essential for sound germplasm conservation and recommendation strategies for production and consumption. The study evaluated biochemical content of 68 sweetpotato genotypes grown at the Miyare Agriculture Training College and Kenya Agricultural and Livestock Research Organization, Embu, Kenya. Ten storage root and seven aerial traits were used in the characterization. Storage root dry matter, protein and total carotenoids contents were all higher at the Miyare Agriculture Training College site compared to the Embu site; storage root sucrose and total starch content were higher in Kenya Agricultural and Livestock Research Organization, Embu, compared to the Miyare Agriculture Training College. Dry matter content ranged from $22.9 \%$ to $41.7 \%$, protein content ranged from $5.2 \%$ to $13.4 \%$, total carotenoids content ranged from $5.9 \mu \mathrm{g} \cdot \mathrm{g}^{-1}$ to $33.1 \mu \mathrm{g} \cdot \mathrm{g}^{-1}$, sucrose content ranged from $11.0 \mathrm{mg} \mathrm{kg}^{-1}$ to $108.5 \mathrm{mg} \mathrm{kg}^{-1}$, and total starch ranged from $9.1 \mathrm{mg} \mathrm{kg}^{-1}$ to $97.6 \mathrm{mg} \mathrm{kg}^{-1}$. The study demonstrates varying biochemical characteristics in sweetpotato, depending on genotypes and location. Selecting and improving sweetpotato genotypes rich in biochemical contents could help to solve the problem of food security and nutrition, especially in developing countries.
\end{abstract}

\section{Introduction}

Most studies on phytochemicals in roots or leaves of sweetpotato [Ipomoea batatas (L.) Lam.] indicated that their health promoting and/or disease preventing benefits were related to the high level of polyphenols [1]. [2] demonstrated that sweetpotato extract offered activity levels of cancer prevention which was correlated with its level of phenolic content. Sweetpotato leaves are rich in proteins, iron, potassium, sodium, vitamin $\mathrm{C}$, vitamin $\mathrm{K}$, folates, minerals, fat, fibre, and carbohydrates. Leaves have low levels of toxicants, except for oxalate, which can be reduced by cooking [1]. Vitamin A deficiency is more severe in sub-Saharan Africa, where an estimated 32\% of preschool aged children are affected and sweetpotato consumption has the potential of solving this problem $[3,4]$.

The concentration of nutrients in sweetpotato pulp depends on variety, and environment. Purple sweetpotatoes have high levels of anthocyanins, and consequently, high antioxidant capacity [5]. Conversely, orange sweetpotatoes are an excellent source of carotenoids [6]. The main characteristic of carotenoids in sweetpotatoes is their provitamin A activity [3]. The extent and distribution of nutritional variation in sweetpotato is essential for sound recommendation strategies for production and consumption to meet the demand for future food security [7]. Sweetpotato varieties can be identified based on their biochemical profiling [5]. Over time, natural hybridization and selection resulted in evolution of hundreds of native sweetpotato cultivars in Kenya [7]. Therefore, there is no distinct sweetpotato variety for commercial recommendation in Kenya. There is a need for evaluation of sweetpotato genotypes grown for their nutritional composition for recommendation to growers and consumers. The objective of the study was to determine the biochemical composition of selected sweetpotato genotypes. 


\section{Materials and Methods}

The experiment was carried out at the Miyare Agriculture Training College (ATC) farm situated in Migori County and the Kenya Agricultural and Livestock Research Organization (KALRO) situated in Embu County. The KALRO-Embu is characterized by altitude of $1497 \mathrm{~m}$ above sea level, an average annual rainfall of $1252 \mathrm{~mm}$, an average annual temperature of $19.5{ }^{\circ} \mathrm{C}$ and humic nitisols. The ATC-Miyare is characterized by altitude of $1300-1620 \mathrm{~m}$ above sea level, an average annual rainfall of $1600-1800 \mathrm{~mm}$, an average annual temperature of $16-17^{\circ} \mathrm{C}$ and humic acrisols.

Sixty-eight sweetpotato genotypes collected in 2013 (Table 1) as vine cuttings were used. The 68 genotypes included 57 local Kenyan landraces and $11 \mathrm{~F}_{1}$ hybrids from a polycross carried out in the National Crops Resources Research Institute, Uganda (Table 1). The genotypes collected from Kenya were from the Western, Nyanza and Eastern regions. The criteria for genotype collection was based on genotypes commonly grown by farmers in the Western region of Kenya and those indicated to have some resistance to weevils (Cylas spp.). The sweetpotato genotypes were multiplied at KALRO-Embu.

The genotypes were planted in a randomized complete block design on 27 March 2014 and 28 April 2014 for ATC-Miyare and KALRO-Embu, respectively. Each plot size was $1.5 \times 3.75 \mathrm{~m}$; plant spacing was $30 \times 75 \mathrm{~cm}$ giving 25 plants per plot. Sweetpotato vines, $30 \mathrm{~cm}$ long, from each genotype, were planted in 5 rows. No pesticides were applied during the course of the experiment. Weeding was carried out once at both sites 6 weeks after planting. The plants were rainfed at both sites. Harvesting was at 160 days after planting. Sweetpotato root samples in each plot were washed, packed and transported to KALRO (Njoro) biochemical laboratory for dry matter, protein, total carotenoids, total starch and sucrose.

Table 1. List of the sweetpotato genotypes used for the study.

\begin{tabular}{lll}
\hline Genotype & Origina & Flesh color \\
\hline Kenspot 1 & Eastern (Kenya) & Yellow \\
Saly boro & Nyanza (Kenya) & Orange \\
$91 / 2187$ & Western (Kenya) & Yellow \\
Oduogo jodongo & Nyanza (Kenya) & White \\
5 Nyandere & Western (Kenya) & Cream-Yellow \\
Odinga & Nyanza (Kenya) & Yellow \\
Naspot 1 & Western (Kenya) & Yellow \\
Kenspot 3 & Eastern (Kenya) & Orange \\
Naspot $\times$ New Kawogo 2 & NaCCRI (Uganda) & Cream \\
Nyamuguta & Western (Kenya) & Cream-white \\
Nyautenge & Western (Kenya) & Cream \\
Ejumula $\times$ New Kawogo 4 & NaCCRI (Uganda) & Yellow-orange \\
Nyarambe & Western (Kenya) & Cream \\
Nyakagwa & Western (Kenya) & Cream \\
Naspot $\times$ New Kawogo 3 & NaCCRI (Uganda) & Yellow-orange \\
Ejumula $\times$ New Kawogo 2 & NaCCRI (Uganda) & Cream \\
Nangili & Western (Kenya) & Yellow-orange \\
Kenspot 2 & Eastern (Kenya) & White \\
SPK 013 & Nyanza (Kenya) & White \\
Mugande $\times$ New Kawogo 4 & NaCCRI (Uganda) & Yellow-orange \\
Alupe-or & Western (Kenya) & Orange \\
12 Marooko & Western (Kenya) & Cream \\
Kenspot 5 & Eastern (Kenya) & Orange \\
36 Kalamb Nyerere & Nyanza (Kenya) & Cream-yellow \\
K/KA $/ 2004 / 215$ & Western (Kenya) & Yellow \\
Ejumula $\times$ New Kawogo 3 & NaCCRI (Uganda) & Yellow \\
\hline & & \\
& & \\
\hline
\end{tabular}




\begin{tabular}{|c|c|c|}
\hline 292-H-12 & Western (Kenya) & Yellow-cream \\
\hline Mogesi Gikenja & Western (Kenya) & White \\
\hline Lungabure & Western (Kenya) & Cream-white \\
\hline Kenspot 4 & Eastern (Kenya) & Orange \\
\hline Vitaa & Nyanza (Kenya) & Cream \\
\hline 9 Nduma & Western (Kenya) & Purple-cream \\
\hline 24 Kampala & Western (Kenya) & Yellow-orange \\
\hline Obugi & Western (Kenya) & Yellow-orange \\
\hline $56682-03$ & Western (Kenya) & Cream \\
\hline Nyawo Nyathiodiewo & Nyanza (Kenya) & Orange \\
\hline Gachaka & Western (Kenya) & Yellow-orange \\
\hline Mugande & Western (Kenya) & White \\
\hline Amina & Nyanza (Kenya) & Orange \\
\hline Fumbara jikoni & Western (Kenya) & Cream \\
\hline Ejumula & Western (Kenya) & Orange \\
\hline Karunde & Nyanza (Kenya) & Cream \\
\hline SPK 004 & Nyanza (Kenya) & Orange \\
\hline Kuny kibuonjo & Nyanza (Kenya) & Cream-white \\
\hline $\mathrm{K} / \mathrm{KA} / 2002 / 12$ & Western (Kenya) & White \\
\hline 55 Nganyomba & Western (Kenya) & Cream \\
\hline 1 Ujili & Western (Kenya) & Yellow \\
\hline Santo Amaro & Rift valley (Kenya) & Cream \\
\hline Mugande $\times$ New kawogo 2 & NaCCRI (Uganda) & Cream \\
\hline Wera & Nyanza (Kenya) & Yellow \\
\hline Kemb 10 & Nyanza (Kenya) & Yellow \\
\hline Mbita & Western (Kenya) & Yellow \\
\hline Naspot $\times$ New Kawogo 1 & NaCCRI (Uganda) & Cream \\
\hline Kibuonjo & Nyanza (Kenya) & Cream-white \\
\hline 29 Kuny kibuonjo & Nyanza (Kenya) & Yellow \\
\hline 62 Odhiogo & Western (Kenya) & Yellow \\
\hline 52 Nyakisumu & Nyanza (Kenya) & Yellow-orange \\
\hline Ejumula $\times$ New kawogo 1 & NaCCRI (Uganda) & Cream \\
\hline Bungoma & Nyanza (Kenya) & Cream \\
\hline K117 & Nyanza (Kenya) & White \\
\hline Fundukhusia & Western (Kenya) & Yellow-orange \\
\hline SPK 031 & Western (Kenya) & Orange \\
\hline Mugande $\times$ New kawogo 1 & NaCCRI (Uganda) & Yellow \\
\hline Mwavuli & Nyanza (Kenya) & Cream \\
\hline Polo yiengo & Nyanza (Kenya) & Yellow \\
\hline Mugande $\times$ New kawogo 3 & NaCCRI (Uganda) & Cream \\
\hline Sinia & Nyanza (Kenya) & Yellow \\
\hline Tainung & Eastern (Kenya) & Orange \\
\hline
\end{tabular}

${ }^{a}$ All crosses in the study are $F_{1}$ hybrids from a polycross obtained from the National Crops Resources Research Institute, Uganda.

Determination of dry matter content was conducted following the method of [8]. Pots were washed in distilled water, labelled and dried in oven at $80{ }^{\circ} \mathrm{C}$. The pots were then sterilized by dry heat in the oven at $105^{\circ} \mathrm{C}$ for $30 \mathrm{~min}$ and placed in the desiccator for $30 \mathrm{~min}$. The weight of the labeled pots was tared by use of the weighing scale. Fresh root samples of sweetpotato were chopped into small pieces of $1 \mathrm{~cm}^{3}$. A sample of $100 \mathrm{~g}$ of chopped fresh roots (from each genotype) were dried in an oven at $105^{\circ} \mathrm{C}$ for $48 \mathrm{~h}$. Dry matter percent was determined. 
Protein analysis was carried out based on standard procedures [9]. One-g catalyst (made up of $1000 \mathrm{~g}$ potassium sulphate, $5 \mathrm{~g}$ selenium and $25 \mathrm{~g}$ copper sulphate mixed together thoroughly) was weighed and put in numbered digestion tubes. One-g of sample was put in a digestion tube and $7.5 \mathrm{~mL}$ concentrated sulphuric acid (nitrogen free) added. This was placed in a digester (Tecator, Hoganas, Sweden) for $30 \mathrm{~min}$ at $398^{\circ} \mathrm{C}$, or until the mix cleared. Samples were removed from the digestion block and left to cool for 20-30 min. After cooling, $25 \mathrm{~mL}$ of distilled water was added to the mix followed by slow addition of $25 \mathrm{~mL} \mathrm{NaOH}$, to avoid a vigorous reaction of the acid and base. Distillation followed after addition of a base, into a conical flask with $0.1 \mathrm{~N}$ boric acid for 4 min which contained bromophenol blue dye. Blue color in boric acid changed to green upon receiving nitrogen in a form of ammonia. This was then back-titrated using $0.1 \mathrm{~N}$ hydrochloric acid which changed color of the mix in the flask from green to blue. The titer volume was recorded and used in calculation of average percent protein. The conversion factor used was 6.25 which are specific for sweetpotato plant sample [9]. The whole process was replicated 3 times with a control consisting of all the reagents and conditions except the experimental samples.

Analysis of sucrose (free sugar) and starch were conducted following the method reported by [10]. About $0.05 \mathrm{~g}$ of flour was weighed into centrifuge tubes. The powder was moistened with $1.0 \mathrm{~mL} \mathrm{95 \%} \mathrm{ethanol.} \mathrm{Afterwards,} 2.0 \mathrm{~mL}$ of distilled water was added, and contents mixed. Then $10.0 \mathrm{~mL}$ of hot $95 \%$ ethanol was added and the mix vortexed. The products were centrifuged (1000 $\times \mathrm{g}$ ) for $10 \mathrm{~min}$. The supernatant was decanted into a $100 \mathrm{~mL}$ volumetric flask and made up to mark. An aliquot of $1.0 \mathrm{~mL}$ of the extract was transferred to a clean test tube then $0.5 \mathrm{~mL} 5 \%$ phenol added and mixed. Afterwards, $2.5 \mathrm{~mL}$ of concentrated $\mathrm{H}_{2} \mathrm{SO}_{4}(98 \%)$ was added and the mix vortexed. After cooling, absorbance at $490 \mathrm{~nm}$ was read and recorded. The $490 \mathrm{~nm}$ wavelength is at which sucrose absorbs the most light. The absorbance of the blank (distilled water) was read. A standard curve was made using $0-100 \mu \mathrm{g} \cdot \mathrm{mL}^{-1}$ using standard sucrose. Sugars (sucrose) obtained after hydrolysis of the residue was converted to starch by multiplying it by 0.9 .

Carotenoids were extracted following the improved method of [11]. About $0.24 \mathrm{~g}$ of sweetpotato fresh tuber samples was weighed and cut into small pieces. The pieces were transferred to a clean test tube with a lid. Diethyl ether $(3 \mathrm{~mL})$ was pipetted and added to the test tube to help dissolve solutes in the sweetpotato. The test tube was wrapped with aluminum foil (to prevent exposure of diethyl to light for prevention of oxidation). The caps of the tubes were wrapped with parafilm to prevent spilling of the liquid. The liquid was taken to a shaker that revolves at $75 \mathrm{rpm}$ to mix the contents. The products were centrifuged for $20 \mathrm{~min}$ at $1300 \times \mathrm{g}$. The supernatant was transferred to a new glass tube (without disturbing the pellet). The UV/visible spectrophotometer were blanked with $1 \mathrm{~mL}$ diethyl ethyl at wavelengths 642, 660 and 470. Readings of each sample were recorded at $470 \mathrm{~nm}, 642 \mathrm{~nm}$ and $660 \mathrm{~nm}$ wavelengths and carotenoids concentration calculated according to the equation of [12].

Data were subjected to analysis of variance (ANOVA) in SAS (ver. 10, SAS Institute Inc, Cary, NC). Data were classified according to genotypes, locations, blocks and replications. Means were separated using Tukey's test at 5\% level of significance. Cluster analysis was done on standardized nutrition data based on the Euclidian distance coefficient and UPGMA using NCSS-pc (ver. 11, Tarragona, Spain). A hierarchical program in NCSS was used to generate dendrograms. Data points with the smaller distances between them were grouped together.

\section{Results}

The ANOVA indicated the main effects of site and genotype affected all measured biochemical characteristics (Table 2); there was no significant interaction between sites and genotypes. Analysis of variance indicated differences in root dry matter content among the genotypes and sites (Table 3). Genotypes that had the highest dry matter content were Kenspot 3 and 9 Nduma. The genotype that had the lowest dry matter content was Tainung. Genotypes from ACT-Miyare had higher dry matter content than those from KALRO-Embu. 
Similarly, there were differences in protein content among the genotypes and sites (Table 3). Genotypes with the highest protein content were Odinga, Nyamuguta, Santo Amaro, and Mbita. The genotype with the lowest protein content was 36 Kalamb Nyerere. Genotypes from ACTMiyare had higher protein content compared with KALRO-Embu.

Differences in total carotenoids content of sweetpotato were significant for both genotypes and sites (Table 3). The genotype with the highest total carotenoids content was Kenspot 2 . The genotype with the lowest total carotenoid content was Gachaka. Genotypes from ACT-Miyare had higher carotenoids content than genotypes from KALRO-Embu.

There were differences in sucrose content among the genotypes and sites (Table 3). The genotype with the highest sucrose content was Ejumula $\times$ New Kawogo 4 . The genotypes with the lowest sucrose content were 292-H-12. Sweetpotato genotypes from KALRO-Embu had higher sucrose content compared with those from ACT-Miyare. Varieties that had high values in sucrose had high values in starch content. Differences in starch content were observed among the genotypes and sites (Table 3). The genotype with the highest starch content was Ejumula $\times$ New Kawogo 4 . The genotype with the lowest starch content was 292-H-12. Sweetpotato genotypes from KALROEmbu had higher starch content than those from ACT-Miyare.

Table 2. Analysis of variance for biochemical characteristics of sweetpotato genotypes at ATCMiyare and KALRO Embu sites.

\begin{tabular}{lllllll}
\hline & & \multicolumn{5}{c}{ Mean square } \\
\hline Source & $\begin{array}{l}\text { Degree of } \\
\text { freedom }\end{array}$ & $\begin{array}{l}\text { Root dry } \\
\text { matter }\end{array}$ & $\begin{array}{l}\text { Root } \\
\text { protein }\end{array}$ & $\begin{array}{l}\text { Root total } \\
\text { carotenoids }\end{array}$ & $\begin{array}{l}\text { Root } \\
\text { sucrose }\end{array}$ & $\begin{array}{l}\text { Root total } \\
\text { starch }\end{array}$ \\
\hline Site $(\mathrm{S})$ & 1 & $626.2^{*}$ & $620.5^{*}$ & $555.4^{*}$ & $2134.6^{*}$ & $2035.8^{*}$ \\
Genotype $(\mathrm{G})$ & 67 & $69.7^{*}$ & $34.1^{*}$ & $31.1^{*}$ & $167.4^{*}$ & $164.2^{*}$ \\
Interaction $(\mathrm{S} \times \mathrm{G})$ & 67 & $30.6 \mathrm{~ns}$ & $43.7 \mathrm{~ns}$ & $49.9 \mathrm{~ns}$ & $214.1 \mathrm{~ns}$ & $210.4 \mathrm{~ns}$ \\
Error $(\mathrm{E})$ & 270 & 1.4 & 0.7 & 2.7 & 19.6 & 0.1 \\
\hline
\end{tabular}

ns not significant or $*$ significant at $\mathrm{p}<0.05$.

Table 3. Means for storage root dry matter, protein, total carotenoids, sucrose and total starch of the 68 sweetpotato genotypes.

\begin{tabular}{|c|c|c|c|c|c|}
\hline Genotype & $\begin{array}{c}\text { Dry } \\
\text { matter } \\
(\%)\end{array}$ & $\begin{array}{c}\text { Root } \\
\text { protein } \\
(\%)\end{array}$ & $\begin{array}{l}\text { Root total } \\
\text { carotenoids } \\
\left(\mu g^{\circ} g^{-1}\right)\end{array}$ & $\begin{array}{c}\text { Root } \\
\text { sucrose } \\
\left(\mathrm{mg}^{\prime} \mathrm{kg}^{-1}\right)\end{array}$ & $\begin{array}{c}\text { Root total } \\
\text { starch } \\
\left(\mathrm{mg} \cdot \mathrm{kg}^{-1}\right)\end{array}$ \\
\hline Kenspot 1 & $36.5 b^{\mathrm{a}}$ & $11.8 \mathrm{ab}$ & $13.2 \mathrm{f}$ & $53.9 \mathrm{~cd}$ & $48.5 \mathrm{~g}$ \\
\hline Saly boro & $36.7 b$ & $9.4 \mathrm{~cd}$ & $10.4 \mathrm{~g}$ & $44.6 \mathrm{e}$ & $40.1 \mathrm{~h}$ \\
\hline $91 / 2187$ & $36.9 b$ & $9.3 \mathrm{~cd}$ & $10.6 \mathrm{~g}$ & $35.0 \mathrm{~g}$ & $32.2 \mathrm{j}$ \\
\hline Oduogo jodongo & $37.2 \mathrm{~b}$ & $12.9 \mathrm{ab}$ & $26.4 \mathrm{c}$ & $28.7 \mathrm{~h}$ & $25.3 \mathrm{k}$ \\
\hline 5 Nyandere & $37.5 b$ & $10.3 \mathrm{c}$ & $9.0 \mathrm{~h}$ & $16.0 \mathrm{k}$ & $14.4 \mathrm{~m}$ \\
\hline Odinga & $38.3 \mathrm{ab}$ & $13.4 \mathrm{a}$ & $8.0 \mathrm{i}$ & $89.6 b$ & $80.6 b$ \\
\hline Naspot 1 & $37.2 \mathrm{~b}$ & $11.1 \mathrm{~b}$ & $7.3 \mathrm{i}$ & $88.5 b$ & $79.6 b$ \\
\hline Kenspot 3 & $40.7 \mathrm{a}$ & $8.0 \mathrm{~d}$ & $9.7 \mathrm{gh}$ & $49.9 \mathrm{de}$ & $45.6 \mathrm{gh}$ \\
\hline Naspot $\times$ New Kawogo 2 & $36.8 b$ & $9.0 \mathrm{~cd}$ & $9.4 \mathrm{gh}$ & $29.0 \mathrm{~h}$ & $26.1 \mathrm{k}$ \\
\hline Nyamuguta & $39.0 \mathrm{ab}$ & $14.1 \mathrm{a}$ & $6.1 \mathrm{j}$ & $65.2 \mathrm{c}$ & $58.6 \mathrm{f}$ \\
\hline Nyautenge & $36.2 b$ & $9.4 \mathrm{~cd}$ & $8.0 \mathrm{i}$ & $28.6 \mathrm{~h}$ & $25.8 \mathrm{k}$ \\
\hline Ejumula $\times$ New Kawogo 4 & $36.9 b$ & $7.4 \mathrm{e}$ & $9.7 \mathrm{gh}$ & $108.5 \mathrm{a}$ & $97.6 \mathrm{a}$ \\
\hline Nyarambe & $37.4 \mathrm{~b}$ & $10.0 \mathrm{c}$ & $9.6 \mathrm{gh}$ & $56.9 \mathrm{~cd}$ & $51.2 \mathrm{~g}$ \\
\hline Nyakagwa & $34.7 \mathrm{~b}$ & $7.7 \mathrm{e}$ & $9.4 \mathrm{gh}$ & $52.1 \mathrm{~cd}$ & $47.8 \mathrm{gh}$ \\
\hline Naspot $\times$ New Kawogo 3 & $38.0 \mathrm{ab}$ & $10.8 \mathrm{~b}$ & $28.4 \mathrm{bc}$ & $33.6 \mathrm{gh}$ & $30.3 \mathrm{j}$ \\
\hline Ejumula $\times$ New Kawogo 2 & $35.4 \mathrm{~b}$ & $10.1 \mathrm{c}$ & $8.4 \mathrm{~h}$ & $59.9 \mathrm{~cd}$ & $53.9 \mathrm{~g}$ \\
\hline Nangili & $36.9 b$ & $9.8 \mathrm{c}$ & $16.5 \mathrm{e}$ & $42.1 \mathrm{f}$ & $37.9 \mathrm{i}$ \\
\hline Kenspot 2 & $39.7 \mathrm{ab}$ & $5.9 \mathrm{~g}$ & $33.1 \mathrm{a}$ & $36.0 \mathrm{~g}$ & $31.9 \mathrm{j}$ \\
\hline SPK 013 & $34.0 \mathrm{bc}$ & $9.9 \mathrm{c}$ & $9.0 \mathrm{~h}$ & $53.2 \mathrm{~cd}$ & $47.9 \mathrm{gh}$ \\
\hline
\end{tabular}




\begin{tabular}{|c|c|c|c|c|c|}
\hline Mugande $\times$ New Kawogo 4 & $32.6 \mathrm{c}$ & $8.6 \mathrm{~d}$ & $13.4 \mathrm{f}$ & $63.1 \mathrm{c}$ & $56.8 \mathrm{f}$ \\
\hline Alupe or & $34.2 b c$ & $9.8 \mathrm{c}$ & $21.9 d$ & $47.7 \mathrm{e}$ & $43.0 \mathrm{~h}$ \\
\hline 12 Marooko & $37.2 \mathrm{~b}$ & $8.0 \mathrm{~d}$ & $17.1 \mathrm{e}$ & $54.4 \mathrm{~cd}$ & $49.0 \mathrm{~g}$ \\
\hline Kenspot 5 & $33.0 \mathrm{bc}$ & $5.2 \mathrm{~g}$ & $19.6 \mathrm{~d}$ & $81.5 b$ & $75.1 \mathrm{c}$ \\
\hline 36 Kalamb Nyerere & $35.9 b$ & $4.2 \mathrm{~h}$ & $8.7 \mathrm{~h}$ & $56.2 \mathrm{~cd}$ & $50.6 \mathrm{~g}$ \\
\hline $\mathrm{K} / \mathrm{KA} / 2004 / 215$ & $32.9 \mathrm{c}$ & $11.0 \mathrm{~b}$ & $9.0 \mathrm{~h}$ & $52.7 \mathrm{~cd}$ & $47.4 \mathrm{gh}$ \\
\hline Ejumula $\times$ New Kawogo 3 & $35.4 b$ & $8.6 \mathrm{~d}$ & $7.7 \mathrm{i}$ & $43.3 \mathrm{f}$ & $39.0 \mathrm{i}$ \\
\hline 292-H-12 & $35.8 b$ & $7.3 \mathrm{e}$ & $6.6 \mathrm{ij}$ & 11.01 & $9.9 \mathrm{n}$ \\
\hline Mogesi Gikenja & $37.1 \mathrm{~b}$ & $10.1 \mathrm{c}$ & $6.7 \mathrm{ij}$ & $35.2 \mathrm{~g}$ & $31.7 \mathrm{j}$ \\
\hline Lungabure & $34.1 b c$ & $7.5 \mathrm{e}$ & $15.5 \mathrm{ef}$ & $29.2 \mathrm{~h}$ & $26.7 \mathrm{k}$ \\
\hline Kenspot 4 & $33.8 \mathrm{bc}$ & $11.4 \mathrm{~b}$ & $30.5 b$ & $22.6 j$ & 20.31 \\
\hline Vitaa & $34.5 b c$ & $9.8 \mathrm{c}$ & $7.0 \mathrm{ij}$ & $50.5 \mathrm{de}$ & $49.1 \mathrm{~g}$ \\
\hline 9 Nduma & $41.4 \mathrm{a}$ & $6.3 \mathrm{f}$ & $6.3 \mathrm{ij}$ & $56.8 \mathrm{~cd}$ & $52.6 \mathrm{~g}$ \\
\hline 24 Kampala & $35.8 b$ & $9.7 \mathrm{c}$ & $7.8 \mathrm{i}$ & $85.0 \mathrm{~b}$ & $76.5 \mathrm{~d}$ \\
\hline Obugi & $37.4 b$ & $10.1 \mathrm{c}$ & $11.4 \mathrm{~g}$ & $61.4 \mathrm{c}$ & $60.8 \mathrm{e}$ \\
\hline $56682-03$ & $33.9 \mathrm{bc}$ & $10.8 b$ & $7.4 \mathrm{i}^{\circ}$ & 49.0de & $44.2 \mathrm{~h}$ \\
\hline Nyawo Nyathiodiewo & $34.0 \mathrm{bc}$ & $10.5 b c$ & $16.2 \mathrm{e}$ & $42.3 \mathrm{f}$ & $37.9 \mathrm{i}$ \\
\hline Gachaka & $34.2 b c$ & $11.9 \mathrm{ab}$ & $5.9 \mathrm{j}$ & $18.6 \mathrm{k}$ & $24.0 \mathrm{k}$ \\
\hline Mugande & $35.8 b$ & $8.7 d$ & $7.3 \mathrm{i}$ & $39.2 \mathrm{fg}$ & $35.3 \mathrm{i}$ \\
\hline Amina & $36.1 b$ & $5.6 \mathrm{~g}$ & $7.8 \mathrm{i}$ & $72.0 \mathrm{c}$ & $64.8 \mathrm{e}$ \\
\hline Fumbara jikoni & $33.9 b c$ & $8.1 \mathrm{~d}$ & $8.4 \mathrm{~h}$ & $53.0 \mathrm{~cd}$ & $47.7 \mathrm{gh}$ \\
\hline Ejumula & $34.9 \mathrm{bc}$ & $6.8 \mathrm{ef}$ & $7.7 \mathrm{i}$ & $38.0 \mathrm{~g}$ & $34.2 \mathrm{i}$ \\
\hline Karunde & $34.9 \mathrm{bc}$ & $8.1 d$ & $16.4 \mathrm{e}$ & $33.1 \mathrm{gh}$ & $29.8 \mathrm{k}$ \\
\hline SPK 004 & $34.2 \mathrm{bc}$ & $10.8 \mathrm{~b}$ & $15.9 \mathrm{ef}$ & $57.5 \mathrm{~cd}$ & $52.6 \mathrm{~g}$ \\
\hline Kunykibuonjo & $33.3 b c$ & $10.9 b$ & $8.8 \mathrm{~h}$ & $78.9 \mathrm{bc}$ & $71.0 \mathrm{~d}$ \\
\hline $\mathrm{K} / \mathrm{KA} / 2002 / 12$ & $34.4 \mathrm{bc}$ & $5.9 \mathrm{~g}$ & $8.6 \mathrm{~h}$ & $51.0 \mathrm{~d}$ & $45.9 \mathrm{gh}$ \\
\hline 55 Nganyomba & $31.8 \mathrm{~cd}$ & $9.3 \mathrm{~cd}$ & $7.7 \mathrm{i}$ & $47.2 \mathrm{de}$ & $42.5 \mathrm{~h}$ \\
\hline 1-Ujili & $33.9 \mathrm{bc}$ & $12.1 \mathrm{ab}$ & $8.6 \mathrm{~h}$ & $37.8 \mathrm{~g}$ & $34.0 \mathrm{i}$ \\
\hline Santo Amaro & $34.1 \mathrm{bc}$ & $13.8 \mathrm{a}$ & $8.7 \mathrm{~h}$ & $53.6 \mathrm{~cd}$ & $48.3 \mathrm{gh}$ \\
\hline Mugande $\times$ New Kawogo 2 & $30.4 \mathrm{~d}$ & $12.2 \mathrm{ab}$ & $6.3 \mathrm{j}$ & $26.6 \mathrm{i}$ & $23.9 \mathrm{k}$ \\
\hline Wera & $33.3 b c$ & $11.4 b$ & $8.4 \mathrm{~h}$ & $27.6 \mathrm{i}$ & $24.8 \mathrm{k}$ \\
\hline Kemb 10 & $32.8 \mathrm{c}$ & $5.9 \mathrm{~g}$ & $12.8 \mathrm{fg}$ & $40.5 \mathrm{fg}$ & $36.4 \mathrm{i}$ \\
\hline Mbita & $31.3 \mathrm{~cd}$ & $13.2 \mathrm{a}$ & $18.0 \mathrm{e}^{\circ}$ & $31.4 \mathrm{~h}$ & $28.2 \mathrm{k}$ \\
\hline Naspot $\times$ New Kawogo 1 & $31.5 \mathrm{~cd}$ & $7.3 \mathrm{e}$ & $7.0 \mathrm{ij}$ & $39.1 \mathrm{~g}$ & $35.2 \mathrm{i}$ \\
\hline Kibuonjo & $32.9 \mathrm{c}$ & $6.9 \mathrm{ef}$ & $6.6 \mathrm{ij}$ & $25.5 \mathrm{i}$ & $23.0 \mathrm{k}$ \\
\hline 29 Kunykibuonjo & $32.6 \mathrm{c}$ & $6.9 \mathrm{ef}$ & $11.3 \mathrm{~g}$ & $43.4 \mathrm{f}$ & $39.6 \mathrm{i}$ \\
\hline 62 Odhiogo & $29.4 d$ & $6.8 \mathrm{ef}$ & $10.1 \mathrm{~g}$ & $35.1 \mathrm{~g}$ & $31.6 \mathrm{j}$ \\
\hline 52 Nyakisumu & $32.3 \mathrm{c}$ & $5.4 \mathrm{~g}$ & $12.1 \mathrm{fg}$ & $43.6 \mathrm{f}$ & $39.3 \mathrm{i}$ \\
\hline Ejumula $\times$ New Kawogo 1 & $33.0 \mathrm{bc}$ & $11.1 \mathrm{~b}$ & $6.1 \mathrm{j}$ & $51.4 \mathrm{~d}$ & $46.2 \mathrm{gh}$ \\
\hline Bungoma & $32.9 \mathrm{c}$ & $5.8 \mathrm{~g}$ & $11.0 \mathrm{~g}$ & 48.4de & $44.1 \mathrm{~h}$ \\
\hline K 117 & $31.1 \mathrm{~cd}$ & $10.0 \mathrm{c}$ & $7.9 \mathrm{i}^{\circ}$ & $46.4 \mathrm{e}$ & $41.8 \mathrm{~h}$ \\
\hline Fundukhusia & $29.5 d$ & $10.9 b$ & $6.9 \mathrm{ij}$ & $43.2 \mathrm{f}$ & $39.7 \mathrm{i}$ \\
\hline SPK 031 & $29.0 \mathrm{~d}$ & $11.2 b$ & $26.5 \mathrm{c}$ & $56.6 \mathrm{~cd}$ & $51.0 \mathrm{~g}$ \\
\hline Mugande $\times$ New Kawogo 1 & 28.4de & $10.9 b$ & $6.5 \mathrm{ij}$ & $41.9 \mathrm{f}$ & $37.7 \mathrm{j}$ \\
\hline Mwavuli & $29.6 \mathrm{~d}$ & $7.6 \mathrm{e}$ & $7.4 \mathrm{i}$ & $80.6 b$ & $72.6 \mathrm{~d}$ \\
\hline Polo yiengo & $27.4 \mathrm{e}$ & $9.9 c$ & $10.6 \mathrm{~g}$ & $23.4 \mathrm{j}$ & 21.01 \\
\hline Mugande $\times$ New Kawogo 3 & $26.6 \mathrm{e}$ & $9.2 \mathrm{~cd}$ & $7.2 \mathrm{ij}$ & $76.9 \mathrm{bc}$ & $69.2 \mathrm{~d}$ \\
\hline Sinia & $27.2 \mathrm{e}$ & $9.3 \mathrm{~cd}$ & $7.4 \mathrm{i}$ & $94.1 b$ & $84.7 \mathrm{~b}$ \\
\hline Tainung & $22.9 f$ & $9.1 \mathrm{~cd}$ & $29.1 b$ & $55.0 \mathrm{~cd}$ & $49.5 \mathrm{~g}$ \\
\hline \multicolumn{6}{|c|}{ Location } \\
\hline ATC-Miyare & $35.4 a$ & $12.9 \mathrm{a}$ & $12.6 \mathrm{a}$ & $44.0 \mathrm{~b}$ & $39.7 b$ \\
\hline KALRO-Embu & $32.9 b$ & $5.7 \mathrm{~b}$ & $10.5 b$ & $54.0 \mathrm{a}$ & $49.0 \mathrm{a}$ \\
\hline
\end{tabular}

${ }^{a}$ values in columns followed by the same letter are not significantly different, Tukey's test, $p<0.05$. 
The dendrogram obtained using combined nutrition characters at both ACT-Miyare and KALRO-Embu, separated genotypes into 2 clusters (Fig. 1). Cluster A contained 2 genotypes (Naspot 1 and Naspot $x$ New Kawango 3); cluster B contained the remaining 66 genotypes. Cluster A consisted of genotypes that had high sucrose, starch and dry matter content. Cluster B consisted of genotypes that had high total carotenoids content and moderately high contents of sucrose and starch.

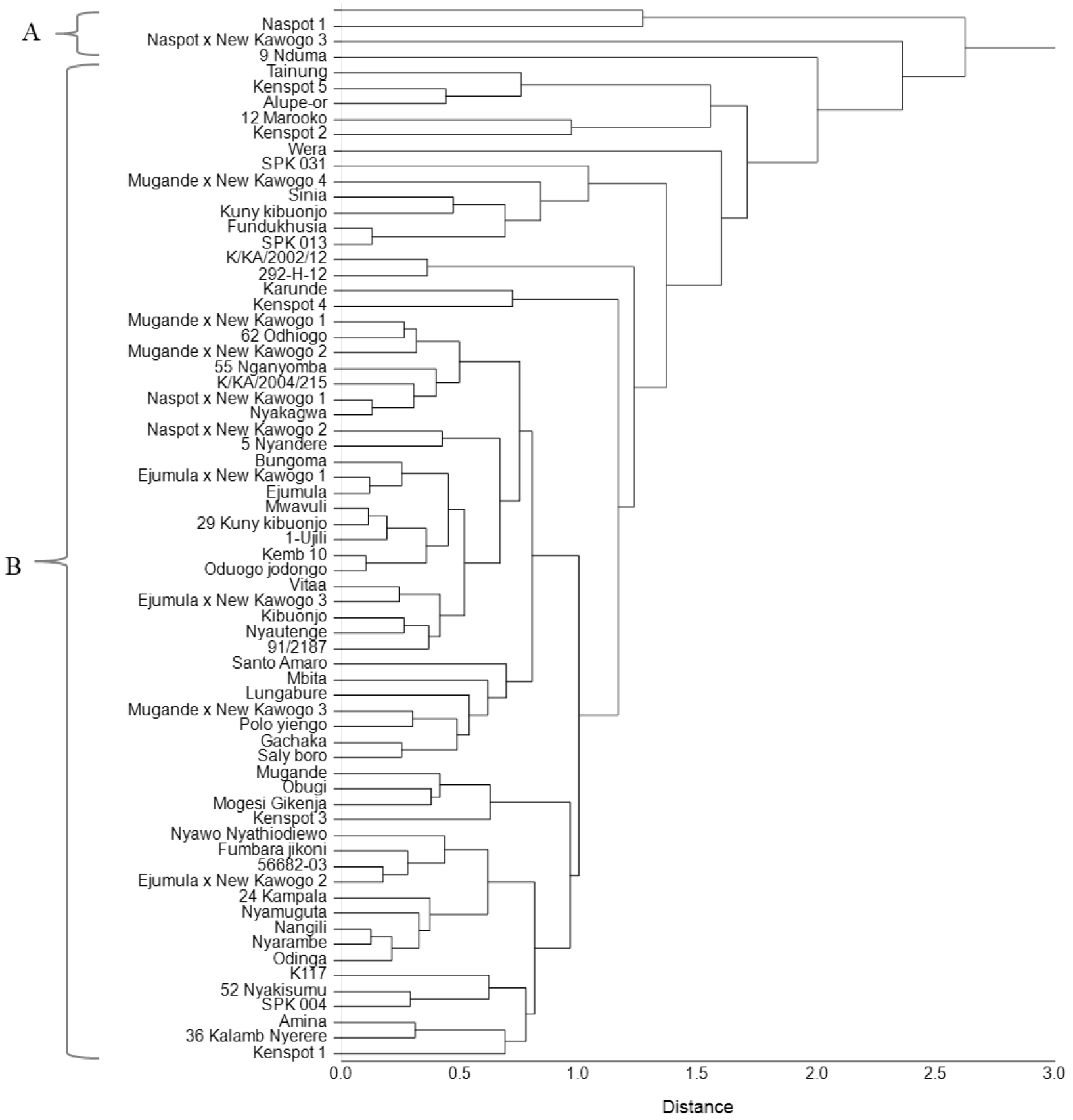

Figure 1. The dendrogram (based on Euclidean distance coefficient) of sweetpotato genotypes generated from combined biochemical data at ACT-Miyare and KALRO-Embu. Genotypes connected by portions of the dendrogram are highly related. As the dendrogram couplets coalesce the genotypes are fit into groups that are related based on root protein, root total carotenoids, root sucrose, and root total starch. Letters (A and B) represent clusters.

\section{Discussion}

The sweetpotato genotypes were evaluated to determine their biochemical diversity. No single genotype was superior in all desirable attributes. Kenspot 3 and 9 Nduma had the highest dry matter content. [13] reported that among farmers' selection criteria for sweetpotato genotypes are high 
yields, early maturity, tolerance to diseases and pests, high dry matter content and taste or sweetness. Therefore, sweetpotato genotypes with high dry matter content as observed in the study could be ideal for recommendation to farmers. Low biochemical content including low dry matter content is among attributes that have led to the abandonment of many varieties by farmers $[14,15]$. Various studies have also reported high biochemical, dry matter content and storage root yield as important characteristics for good sweetpotato varieties [16, 17, 18]. Root dry matter content is influenced by genetic constituents, therefore, explaining the biochemical differences within the studied genotypes [19]. Biochemical content of sweetpotato varies with variety, location, climate, the incidence of pests and diseases, cultural practices and soil type [20, 21]. This could further explain the location differences in dry matter content. The results of this study agree with [1] and [18] who observed varying biochemical differences to be a common phenomenon to East African genotypes. Use of sweetpotato as a raw material for the biofuel and processing industries requires genotypes with a dry matter content that is above $35 \%$ of the fresh weight [19]. According to the results of this study, majority of genotypes are suitable to serve as effective raw material for processing. Genotype Kenspot 2 had the highest total carotenoids content, making it suitable for addressing vitamin A deficiency [3]. Genotypes rich in protein such as Odinga, Santo Amoro, and Mbita could be recommended for children and the sick. Genotype Ejumula $\times$ New Kawogo 4 was observed to have a high content of starch and sucrose. Sweetness is among farmer selection criteria for sweetpotato genotypes in Eastern and Southern Africa. Most farmers prefer genotypes that are sweet (contain high contents of sucrose); some prefer genotypes that are less sweet. Genotypes with high sucrose content can enhance carbohydrate uptake by individuals while less sweet genotypes can be used can be used to fortify cereal products.

The dendrogram indicated that genotypes did not cluster together uniformly in all trees. The trees could only give the general germplasm relatedness and diversity. The probable reason as to why clustering was not uniform is that expressions of biochemical characters are environmentally dependent [19, 22]. High ploidy level in sweetpotato may be responsible for variability in nutritional composition due to increased mutation associated with polyploidy [23].

\section{Conclusions}

The findings demonstrate that sweetpotato genotypes have varying biochemical characteristics depending on the growing location, attributed to environmental influence and growing conditions. Selecting and improving sweetpotato genotypes rich in biochemical contents could help to solve the problem of food security and nutrition, especially in developing countries.

\section{Acknowledgement}

I express profound gratitude and appreciation to the following persons, without whose contribution, this work would not have been possible: Prof. Stephen Githiri, Prof. Bernard Nyende and Dr. Lucy K. Murungi for their scientific support and guidance throughout the research process. I thank the administration of ATC-Miyare and KALRO-Embu for allowing me to conduct my fieldwork in their facility.

\section{Conflict of Interest}

The author declares that there is no conflict of interest. 


\section{References}

[1] M. Dinu et al., Analysis of nutritional composition and antioxidant activity of sweetpotato (Ipomoea batatas L.) leaf and petiole, Journal of Applied Botany and Food Quality. 91 (2018) 120-125. doi:10.5073/JABFQ.2018.091.017.

[2] L. Fukumoto, G. Mazza, Assessing antioxidant and prooxidant activity of phenolic compounds, Journal of Agricultural and Food Chemistry. 48 (2000) 3597-3604. doi: $10.1021 / \mathrm{jf000220 \textrm {w } .}$

[3] B.J. Burri, Evaluating Sweetpotato as an intervention food to prevent Vitamin A deficiency, Comprehensive Reviews in Food Science and Food Safety. 10 (2011) 118-130. doi: 10.1111/j.1541-4337.2010.00146.x.

[4] S. McGuire, FAO, IFAD, \& WFP. The state of food insecurity in the World 2015: Meeting the 2015 international hunger targets: taking stock of uneven progress, Advanced Nutrition. 6 (2015) 623-624.

[5] M. Vizzotto et al., Physicochemical and antioxidant capacity analysis of colored sweetpotato genotypes: in natura and thermally processed, Ciência Rural, Santa Maria. 47 (2017) 1-8. doi: $10.1590 / 0103-8478 \mathrm{cr} 20151385$.

[6] L.M. Zhang, Q.M. Wang, Y.X. Wang, The main nutrient components and health care function of sweetpotato, Rain Fed Crops. 23 (2003) 162-166.

[7] H.W. Karuri et al., Morphological markers cannot reliably identify and classify sweetpotato genotypes based on resistance to sweetpotato virus disease and dry matter content, Journal of Applied Biosciences. 15 (2009) 820-828.

[8] A.P. Asare, Determination of dry matter content of cassava tubers, B.Sc dissertation, University of Cape Coast. Cape Coast, Ghana, 2004.

[9] Official Methods of Analysis, volume 1. Association of Official Analytical Chemists, Gaithersburg, MD., 1992.

[10] D. Smith, G.M. Paulsen, C.A. Raguse, Extraction of total available carbohydrates from grass and legume tissue, Plant Physiology. 39 (1964) 960-962.

[11] A.R. Wellburn, The spectral determination of chlorophylls a and b, as well as total carotenoids, using various solvents with spectrophotometers of different resolution, Journal of Plant Physiology. 144 (1994) 307-313. doi: 10.1016/S0176-1617(11)81192-2.

[12] H.K. Lichtenthaler, Chlorophylls and carotenoids: Pigments of photosynthetic biomembranes, Methods in Enzymology. 148 (1987) 350-382. doi: 10.1016/0076-6879(87)48036-1.

[13] F. Tairo, E. Mneney, A. Kullaya, Morphological and agronomical characterization of Sweetpotato [Ipomoea batatas (L.) Lam.] germplasm collection from Tanzania, African Journal of Plant Science. 2 (2008) 77-85.

[14] S. Ngailo et al., Assessment of sweetpotato farming systems, production constraints and breeding priorities in eastern Tanzania, South African Journal of Plant and Soil. 33 (2016) 105-112. doi: 10.1080/02571862.2015.1079933.

[15] D. Shumbusha, Diallel analysis of root dry matter content in sweetpotato, Proceedings 2nd RUFORUM Biennial Meeting, Entebbe, Uganda, 20-24 September, 2010.

[16] N.A. Onunka, Varietal response of three sweetpotato varieties to different rates of a mixture of organic and inorganic fertilizer, Annual Report of the National Root Crops Research Institute, Umudike, Nigeria, 2006.

[17] K.V.A. Richardson, Tuber quality and yield of six sweetpotato varieties evaluated during 2012. Gladstone Road Agricultural Centre Crop Research Report. 13 (2012) 1-13. 
[18] H. Ji et al., Analysis on the nutrition composition and antioxidant activity of different types of sweetpotato cultivars, Food and Nutrition Sciences. 6 (2015) 161-167. doi: $10.4236 /$ fns. 2015.61017

[19] W.J. Gruneberg et al., Genotype $\times$ environment interaction for a diverse set of sweetpotato genotypes evaluated across varying ecogeographic conditions in Peru, Crop Science. 45 (2005) 2160-2171.

[20] S.A.M. Moussa, H.A. Abd El-Aal, N.I. Abo El-Fadl, Stability study of sweetpotato yield and its component characters under different environments by regression analysis, Journal of Horticultural Science and Ornamental Plants. 3 (2011) 43-54.

[21] B. Vimala, B. Hariprakash, Variability of morphological characters and dry matter content in the hybrid progenies of sweetpotato (Ipomoea batatas L.) Lam.], Gene Conserve. 10 (2011) 65-86.

[22] F. Gurmu, S. Hussein, M. Laing, Genotype $\times$ environment interaction and stability of sweetpotato genotypes for root dry matter, $\beta$-carotene and fresh root yield, Open Agriculture. 2 (2017) 473-485. doi: 10.1515/opag-2017-0052.

[23] P.E. Norman et al., Agro-phenotypic characterization of sweetpotato (Ipomoea batatas L.) genotypes using factor and cluster analyses, Agricultural Science Research Journal. 4 (2014) 30-38. 